Received, August $6^{\text {th }} 2018$ Accepted, August $13^{\text {th }} 2018$

Link to DOI:

10.25220/WNJ.V02.i1.0004

Journal Website: www.worldnutrijournal.org

\section{Early Detection of Childhood Obesity Through Extended Routine Growth Monitoring of Children Below Two Years of Age in Asia Pacific Region}

Leilani Muhardi, ${ }^{1}$ Eline M. van der Beek,${ }_{7}^{2,3}$ Marieke Abrahamse-Berkeveld, ${ }^{4}$ Hamid Jan b. Jan Mohamed, ${ }^{5}$ Ngee Lek, ${ }^{6}$ Wendy H. Oddy, ${ }^{7}$ V.Pujitha Wikramasinghe ${ }^{8}$

1. MD, MSc, Head of Healthcare Nutrition Science- Danone Nutricia Early Life Nutrition Indonesia PhD, Research Director, Nutricia Research, Utrecht, The Netherlands

3. Professor, Nutritional Programming, Department of Pediatrics, University Medical Center Groningen, The Netherlands

4. PhD, Developmental and Physiology, Nutricia Research, Utrecht, The Netherlands

5. PhD, Associate Professor, Nutrition and Dietetics Program, School of Health Sciences, Universiti Sains Malaysia, Malaysia

6. FRCPCH, Senior Consultant, Department of Pediatrics, KK Women's and Children's Hospital, Singapore; and Assistant Professor, Duke-NUS Medical School, National University of Singapore

7. PhD, Professorial Research Fellow, Nutritional Epidemiology, Menzies Institute for Medical Research, University of Tasmania, Australia

8. $M D, P h D$, Professor, Department of Paediatrics, University of Colombo, Sri Lanka

\section{Corresponding author:}

Leilani Muhardi

Cyber 2 Tower, $15^{\text {th }}$ Floor

Jl. HR. Rasuna Said Blok X-5 No. 13

South Jakarta 12950, Indonesia

Email:Leilani.muhardi@danone.com

\section{Introduction}

Several cohorts in Europe and Asia have traced the origins of childhood obesity to the first year of life attributing it to differences in BMI development. ${ }^{1-3}$ In 2014, the World Health Organization (WHO) 
estimated that about 41 million children under five year of age were overweight or obese, of which $48 \%$ live in Asia. ${ }^{4}$ Current growth monitoring practices among young children are traditionally targeted to detect under-nutrition and any upward deviations are considered favourable.

Asians are reported to have significantly more body-fat per kilogram body weight than Caucasians which is typically referred to as the "thin-fat phenotype". 5 Although it is clear that origins of childhood obesity are from early childhood, current growth monitoring practices were not used for early detection of excess adiposity. However, because of the epidemic of childhood obesity and its contribution to an ever increasing prevalence of non-communicable diseases, it is of paramount importance that excess gains of adiposity are identified early in life.

This overview aims to evaluate the potential of early detection of obesity (risk) among experts through addition of specific growth monitoring assessments in children during the first two years of life.

\section{Methods}

Experts from the field of infant growth (paediatricians, researchers, nutritionists) from Asia Pacific and Europe met in 2013 to discuss practices and potential research gaps in growth and body composition assessment of children in the Asia Pacific region. Although qualitative approach using Delphi method was not administered, one highlighted area was how to include effective anthropometric measurements in early growth monitoring to detect excess adiposity gain. Some of the practices and the gaps in this sphere were highlighted in this review.

\section{Discussion}

Current routine growth monitoring in selected Asia Pacific countries

The four countries included for assessment (Sri Lanka, Malaysia, Singapore, Australia) may not be representative of the whole of the Asia Pacific region, however they are at different stages of economic development with varied burdens of overweight and obesity. Current growth monitoring practices in these countries are primarily conducted to monitor physical growth (weight, height and head circumference) as a whole and not to evaluate changes in body composition (Table 1) with differences in practice influenced by the availability of resources' and national requirements.

\section{Challenges in measuring body composition in early life}

Several methods are well-established to assess body composition among adults (Air Displacement Plethysmography (ADP), Dual-Energy X-ray Absorptiometry (DEXA) and Body Impedance Analysis (BIA)). However, sensitivity and practicality of these tests to assess fat deposition in children during the first two years of life requires further validation and research.

An alternative yet sensitive assessment which could be implemented in daily practice using a simple tool is skinfold thickness (SFT). ${ }^{6}$ This consists of individual values from the independent assessment of subscapular, supra-iliac, biceps and triceps skinfolds or combined central or peripheral SFT or the sum of four sites (S4SFT) or specific SFT ratios. The S4SFT is identified as a good predictor of the changes in the fat mass during the first year of life and measures are required for younger children. ${ }^{7,8}$ S4SFT within the first few months of life has been associated with cardiovascular health risk with an increase of aortic intima media thickness at 6 weeks ${ }^{9}$ and obesity risk at 6 years of age (OR 1.61, 95\% CI 1.09, 2.38). ${ }^{10}$

Measurement of SFT has several requirements for successful implementation that include a standard protocol, adequate training of the measurement techniques to avoid observer variability $^{11}$ (because it takes longer than standard anthropometry to complete) and translation of S4FT into an estimated total body fat mass for Asian children. The existing limited translation is due to a lack of population specific equations as existing equations have not yet been validated for Asian populations in younger age. ${ }^{12}$ 
Table 1. Overview of current practices for growth monitoring among children 0-5 years of age across the four countries

\begin{tabular}{|c|c|c|c|c|}
\hline Countries/ Practices & Sri Lanka & Malaysia & Singapore & Australia \\
\hline Demographics & $\begin{array}{l}\text { Birth rate: } 20 / 1000 \\
\text { birth, GDP: } \$ 3,368 \text {. } \\
\text { Prevalence of } \\
\text { childhood } \\
\text { overweight: } 6.1 \%\end{array}$ & $\begin{array}{l}\text { Birth rate: } 17 / 1000 \\
\text { birth, GDP: } \\
\$ 10,878 \text {. Prevalence } \\
\text { of childhood } \\
\text { overweight: } 12-16 \%\end{array}$ & $\begin{array}{l}\text { Birth rate: } 9.7 / \\
1000 \text { birth, GDP: } \$ \\
51,855 . \text { Prevalence } \\
\text { of childhood } \\
\text { overweight: } 12- \\
16 \%\end{array}$ & $\begin{array}{l}\text { Birth rate: } \\
12.8 / 1000 \text { birth, } \\
\text { GDP: } \$ 54,708 \text {. } \\
\text { Prevalence of } \\
\text { childhood } \\
\text { overweight: } 25 \%\end{array}$ \\
\hline $\begin{array}{l}\text { Venue and personnel } \\
\text { to monitor growth }\end{array}$ & $\begin{array}{l}\text { Medical Officer of } \\
\text { Health at every } \\
\text { village }\end{array}$ & $\begin{array}{l}\text { Hospitals, general } \\
\text { clinics, maternal \& } \\
\text { child clinic (nurses) }\end{array}$ & $\begin{array}{l}\text { well-child clinics } \\
\text { in government-run } \\
\text { polyclinics and } \\
\text { private } \\
\text { paediatrician } \\
\text { offices. }\end{array}$ & $\begin{array}{l}\text { child health nurses } \\
\text { in well-child clinics } \\
\text { in community } \\
\text { hospitals and } \\
\text { private paediatrician } \\
\text { offices. }\end{array}$ \\
\hline Recording system & $\begin{array}{l}\text { Child Health } \\
\text { Development record } \\
\text { (50 page) }\end{array}$ & $\begin{array}{l}\text { Health book (118 } \\
\text { page) }\end{array}$ & Health book & $\begin{array}{l}\text { "Purple" growth and } \\
\text { development book. }\end{array}$ \\
\hline $\begin{array}{l}\text { Anthropometric } \\
\text { measures }\end{array}$ & $\begin{array}{l}\text { weight, length/ } \\
\text { height, head } \\
\text { circumference }\end{array}$ & $\begin{array}{l}\text { weight, length/ } \\
\text { height, head } \\
\text { circumference }\end{array}$ & $\begin{array}{l}\text { weight, length and } \\
\text { head } \\
\text { circumference }\end{array}$ & $\begin{array}{l}\text { weight, length and } \\
\text { head circumference }\end{array}$ \\
\hline $\begin{array}{l}\text { Frequency of } \\
\text { assessment }\end{array}$ & $\begin{array}{l}\text { monthly up to } 24 \\
\text { months of age, then } \\
2-3 \text { monthly from } 3- \\
5 \text { years of age. }\end{array}$ & $\begin{array}{l}\text { monthly for the first } \\
6 \text { months, every } 2 \\
\text { months for the } \\
\text { second } 6 \text { months, } \\
\text { every } 3 \text { months } \\
\text { between } 1-3 \text { years } \\
\text { of age, every } 6 \\
\text { months between } 2-4 \\
\text { years of age and } \\
\text { annually between } 4- \\
6 \text { years of age }\end{array}$ & $\begin{array}{l}1 \text { month, } 3 \text { months, } \\
4 \text { months, } 5 \\
\text { months, } 6 \text { months, } \\
9 \text { months, } 15 \\
\text { months and } 18 \\
\text { months. }\end{array}$ & $\begin{array}{l}1 \text { month, } 3 \text { months, } \\
4 \text { months, } 5 \text { months, } \\
6 \text { months, } 9 \text { months, } \\
15 \text { months and } 18 \\
\text { months. }\end{array}$ \\
\hline
\end{tabular}

\section{A call for action for daily practice and further research}

As currently used anthropometric measures do not provide an opportunity for the detection of increased adiposity during early life, a measure of SFT could be used as an alternative. S4SFT has shown to be an accurate, practical, relatively low cost and easy to implement measure of fat mass in various cross-sectional and longitudinal studies amongst younger children., ${ }^{7,10}$

To enable the use of S4SFT as part of routine growth assessment, several initiatives need to be taken that include a feasibility study on the use of S4SFT in day to day practice; a concise but comprehensive easy-to-use measurement protocol, validation with other gold standard methods, standard reference to identify intervention levels, and comprehensive training for staff. Costeffectiveness studies and a referral system when adverse levels of adiposity are detected are also important. $^{13}$

There could be increased pressure in the implementing these initiatives to measure all children in a busy clinic. Therefore, measurement of S4SFT could be a required assessment after initial screening using traditional anthropometry for children at risk for overweight/ obesity. Adopting 
S4SFT measures into routine child health monitoring would assist in early detection of children at risk of excess adiposity and introducing this initiative into each country's national program of healthcare is of paramount importance.

\section{Conflict of Interest}

Leilani Muhardi, Eline $M$ van der Beek and Marieke Abrahamse-Berkeveld are employees of Danone Nutricia Research-Early Life Nutrition. None of the other authors have conflict of interest. No educational grant is provided to the rest of authors. Ethical Approval is not obtained as the manuscript is based on observation of current practice.

\section{Open Access}

This article is distributed under the terms of the Creative Commons Attribution 4.0 International Liscence (http://creativecommons.org/licenses/by/4.0/), which permits unrestricted use, distribution, and reproduction in any medium, provided you give appropriate credit to the original author(s) and the source, provide a link to the Creative Commons license, and indicate if changes were made.

\section{Acknowledgement}

We thank Dr. Sophie Leung from Hong Kong and Dr. Andreas Trabesinger from Reinschrift Science Communication, Switzerland and Dr. Eddy Saputra Leman from Nutricia Research for their critical review of the writing. Dr. Eline van der Beek was previously the Research Director at Nutricia Research, Singapore.

\section{References}

1. Druet C, Stettler N, Sharp S, Simmons RK, Cooper C, Smith GD, et al. Prediction of childhood obesity by infancy weight gain: an individual-level meta-analysis. Paediatr Perinat Epidemiol. 2012;26(1):19-26.

2. Willers SM, Brunekreef B, Smit HA, van der Beek EM, Gehring U, de Jongste C, et al. BMI development of normal weight and overweight children in the PIAMA study. PloS one. 2012;7(6):e39517.

3. Hui LL, Wong MY, Lam TH, Leung GM, Schooling CM. Infant growth and onset of puberty: prospective observations from Hong Kong's "Children of 1997" birth cohort. Ann Epidemiol. 2012;22(1):43-50.

4. Swinburn B, Vandevijvere S. WHO report on ending childhood obesity echoes earlier recommendations. Public Health Nutr. 2016;19(1):1-2.

5. Yajnik CS, Fall CH, Coyaji KJ, Hirve SS, Rao S, Barker DJ, et al. Neonatal anthropometry: the thin-fat Indian baby. The Pune Maternal Nutrition Study. Int J Obes Relat Metab Disord. 2003;27(2):173-80.

6. Simmonds M, Burch J, Llewellyn A, Griffiths C, Yang $\mathrm{H}$, Owen $\mathrm{C}$, et al. The use of measures of obesity in childhood for predicting obesity and the development of obesity-related diseases in adulthood: a systematic review and meta-analysis. Health Technol Assess. 2015;19(43):1-336.

7. Aris IM, Soh SE, Tint MT, Liang S, Chinnadurai A, Saw SM, et al. Body fat in Singaporean infants: development of body fat prediction equations in Asian newborns. European journal of clinical nutrition. 2013;67(9):922-7.

8. Yeung D-SH, SS-C. Validity and reliability of skin fold thickness in assessing body fatness. Asia Pacific Journal of Nutrition. 2010;19:350357.

9. McCloskey K, Burgner D, Carlin JB, Skilton MR, Cheung M, Dwyer T, et al. Infant adiposity at birth and early postnatal weight gain predict increased aortic intima-media thickness at 6 weeks of age: a populationderived cohort study. Clin Sci (Lond). 2016;130(6):44350.

10. Santos S, Gaillard R, Oliveira A, Barros H, AbrahamseBerkeveld M, van der Beek EM, et al. Associations of Infant Subcutaneous Fat Mass with Total and Abdominal Fat Mass at School-Age: The Generation R Study. Paediatr Perinat Epidemiol. 2016.

11. Cicek B, Ozturk A, Unalan D, Bayat M, Mazicioglu MM, Kurtoglu S. Four-site skinfolds and body fat percentage references in 6-to-17-year old Turkish children and adolescents. J Pak Med Assoc. 2014;64(10):1154-61.

12. Wickramasinghe VP, Lamabadusuriay SP, Cleghorn GJ, Davies PS. Use of skin-fold thickness in Sri Lankan children: comparison of several prediction equations. Indian journal of pediatrics. 2008;75(12):1237-42.

13. West J, Santorelli G, Lennon L, O'Connell K, Corkett J, Wright $\mathrm{J}$, et al. Beyond height and weight: a programme of school nurse assessed skinfold measurements from white British and South Asian origin children aged 4-5 years within the Born in Bradford cohort study. BMJ Open. 2015;5(11):e008630. 